\title{
Syndrome of Inappropriate Antidiuretic Hormone Associated with Crimean-Congo Hemorrhagic Fever
}

\author{
Kırım-Kongo Hemorajik Ateşi Olan Vakada Uygunsuz Anti-diüretik Hormon Sendromu
}

\section{Samet Özer, Nafia Özlem Kazancı, Ergün Sönmezgöz, Erhan Karaaslan, Resul Yılmaz}

Gaziosmanpaşa Üniversitesi Tıp Fakültesi, Çocuk Sağlığı ve Hastalıkları Ana Bilim Dalı, Tokat, Türkiye

\begin{abstract}
Crimean-Congo hemorrhagic fever (CCHF) is a potentially fatal systemic disease in children caused by a tick- borne virus. Many different clinical and laboratory findings are seen in CCHF. We report here an atypical presentation of CCHF with hyponatremia. CCHF with electrolyte imbalance is not reported before.

A 4-year-old girl presented with fever, fatigue and unconsciousness with hyponatremia.

Based on the clinical and epidemiological findings, virus infection was suspected. Hyponatremia is has never been reported in CrimeanCongo hemorrhagic fever (CCHF), as was observed in this case.

The diagnosis was confirmed by detection of IgM antibody to CCHFvirus and positive Real-Time PCR. We report the first case of imported CCHF presenting as hyponatremia. This electrolyte imbalance has never been reported before in CCHF in children, and the clinician should consider this entity in complications to explain unconsciousness. (Turkiye Parazitol Derg 2014; 38: 275-7)
\end{abstract}

Keywords: Crimean-Congo hemorrhagic fever, electrolyte imbalance, syndrome of inappropriate antidiuretic hormone (SIADH)

Received: 05.03.2014

Accepted: 17.07.2014

\section{ÖZET}

Kırım Kongo Hemorajik Ateşi (KKHA) çocukluk çağında fatal seyirli kene tutunması sonucu ortaya çıkan klinik tablodur. Çok çeşitli klinik ve laboratuvar bulguları ile karşımıza çıkabilir. Bu yazıda atipik bir prezentasyon olan hiponatremi ve bilinç bulanıklığı ile başvuran olgu sunulmuştur. KKHA'nde hiponatremi daha önce bildirilmemiştir.

Olguda 4 yaşında kız hasta ateş, halsizlik ve hiponatremiye bağlı bilinç bulanıklığı ile başvurdu. Hastanın kırsal kesimden başvuruyor olması ve Tokat yöresinde KKHA vakalarının çok sayıda olmasından dolayı KKHA virüsü enfeksiyonundan şüphelenildi. KKHA virüsüne karşı lgM antikorlarının ve Real-Time PCR ile virüsün saptanması ile tanı doğrulandı.

Bu vakayı daha önce KKHA vakalarında elektrolit dengesizliğinin bildirilmemiş olması ve hiponatreminin neden olabileceği bilinç bulanıklığı ve konvülziyon gibi klinik tablolarla karşılaşılabileceğini vurgulanmak amacıyla sunduk. (Turkiye Parazitol Derg 2014; 38: 275-7)

Anahtar Sözcükler: Kırım-Kongo hemorajik ateş, elektrolit dengesizliği,uygunsuz anti-diüretik hormon sendromu

Geliş Tarihi: 05.03.2014

Kabul Tarihi: 17.07.2014

\section{This study is presented in the $3^{\text {th }}$ PUADER Congress, 30 April-4 May 2014, Antalya, Turkey. \\ Bu çalışma "3. PUADER Kongresi"nde sunulmuştur, 30 Nisan-4 Mayıs 2014, Antalya, Türkiye.}

Address for Correspondence / Yazışma Adresi: Dr. Samet Özer, Gaziosmanpaşa Üniversitesi Tıp Fakültesi, Çocuk Sağlığı ve Hastalıkları Ana Bilim Dalı, Tokat, Türkiye. Phone: +90 5532458645 E-mail: sozerdr@hotmail.com

DOI: $10.5152 /$ tpd.2014.3603

CCopyright 2014 Turkish Society for Parasitology - Available online at www.tparazitolderg.org

CTelif hakkı 2014 Türkiye Parazitoloji Derneği - Makale metnine www.tparazitolderg.org web sayfasından ulaşılabilir. 


\section{INTRODUCTION}

Crimean-Congo hemorrhagic fever(CCHF) is a tick-borne fatal systemic disease caused by Nairovirus, which belongs to the Bunyaviridae family and causes severe diseases in humans, with the reported mortality rate of 5-30\% (1). Crimean-Congo hemorrhagic fever virus (CCHFV) is transmitted to humans through bites of infected ticks or direct contact with viremic animals, humans, or contaminated secretions (2). CCHF has a short incubation period and is characterized by a sudden onset of fever, fatigue, headache, dizziness, nausea, vomiting, diarrhea, abdominal pain and elevated liver enzymes, leucopenia, thrombocytopenia, coagulopathy and other hemorrhagic manifestations develop, ranging from petechiae to large areas of ecchymosis $(2,3)$.

There are many etiologic factors underlying unconsciousness. In all these factors, electrolyte imbalance, especially hyponatremia, is a very important entity. Hyponatremia symptoms are nausea, anorexia, emesis, malaise, lethargy, confusion, agitation, headache, seizures, muscle cramps, weakness, coma, and decreased reflexes. Most symptoms of hyponatremia are due to the decrease in extracellular osmolality (4).

\section{CASE REPORT}

A 4-year-old previously healthy girl was admitted to the pediatric emergency department of Gaziosmanpaşa University Medical Practice and Research Center (a tertiary health care facility in the region). Her complaints started 4 days before admission, with fever, fatigue and lethargy. She had no history of tick bite.

On admission, her body temperature was $38.9^{\circ} \mathrm{C}$, blood pressure was $90 / 60 \mathrm{mmHg}$, heart rate was 125 beats/min. White blood cell (WBC) count was $3.3 \times 10^{3} / \mu \mathrm{L}$, hemoglobin $(\mathrm{Hb}) 11.3 \mathrm{~g} / \mathrm{dL}$, and platelet count $46 \times 10^{3} / \mu \mathrm{L}$, aspartate aminotransferase (AST) 266 $\mathrm{IU} / \mathrm{L}$, alanine aminotransferase (ALT) $110 \mathrm{IU} / \mathrm{L}$, creatine kinase (CK) $277 \mathrm{IU} / \mathrm{L}$ and lactate dehydrogenase (LDH) $567 \mathrm{IU} / \mathrm{L}$, creatinine $0.39 \mathrm{mg} / \mathrm{dL}$, glucose $86 \mathrm{mg} / \mathrm{dL}, \mathrm{Na} 124 \mathrm{mmol} / \mathrm{L}, \mathrm{K} \mathrm{4,86} \mathrm{mmol} / \mathrm{L}$, blood urea nitrogen (BUN) $6.9 \mathrm{mg} / \mathrm{dL}$, albumin $3.6 \mathrm{~g} / \mathrm{dL}$, protrombin time (PT) $10.3 \mathrm{~s}$, activated partial thromboplastin time (aPTT) $40.3 \mathrm{~s}$, urine $\mathrm{Na} 217 \mathrm{mmol} / \mathrm{L}$. Following the morning of admission, it was seen that she had maculopapular rashes, and she was still lethargic on examination. WBC was $2.9 \times 10^{3} / \mathrm{L}, \mathrm{Hb} 11 \mathrm{~g} / \mathrm{dL}$ and platelet count $22.7 \times 10^{3} / \mathrm{L}, \mathrm{Na} 124 \mathrm{mmol} / \mathrm{L}, \mathrm{K} .3 .8 \mathrm{mmol} / \mathrm{L}$, AST $239 \mathrm{IU} / \mathrm{L}, \mathrm{ALT} 95 \mathrm{IU} / \mathrm{L}$. The patient was then administered 1 unit of platelets. On another morning, platelet count was $44 \times 10^{3} / \mathrm{L}$, but she had epistaxis and abdominal pain. Because of this coagulopathy, apheresis thrombocyte was given, and she had nasal acking. Abdominal ultrasound imaging revealed that liver craniocaudal length was $105 \mathrm{~mm}$ and had slightly increased, and she had splenomegaly. Thereafter, platelet count was $66.7 \times 10^{3} / \mathrm{L}$, and bleeding was stopped. On the same day, sodium deficit was calculated. $\mathrm{Na}$ replacement treatment was administered. Serum osmolality was $237.2 \mathrm{mOsm} / \mathrm{kg} \mathrm{H} \mathrm{H}_{2}$, and urine osmolality was $413 \mathrm{mOsm} / \mathrm{kg}$ $\mathrm{H}_{2} \mathrm{O}$, and urine $\mathrm{Na}$ level was $217 \mathrm{mmol} / \mathrm{L}$. Blood pressure was within the normal range, she had no edema and hypervolemia. After day, $\mathrm{Na}$ level was $130 \mathrm{mmol} / \mathrm{L}$, and lethargy was started to recruit. She was oriented and cooperative. The following day, $\mathrm{Na}$ level was $137 \mathrm{mmol} / \mathrm{L}$. We decided that lethargy was associated with hyponatremia. After 5 days from admission, $\mathrm{Na}$ level reached $139 \mathrm{mmol} / \mathrm{L}$, platelet count $115 \times 10^{3} / \mathrm{L}$ and WBC 6.9103/L, $\mathrm{Hb}$ 10.1 g/dL, AST $53 \mathrm{IU} / \mathrm{L}$, ALT $45 \mathrm{IU} / \mathrm{L}, \mathrm{LDH} 431 \mathrm{IU} / \mathrm{L}, \mathrm{Na} 138 \mathrm{mmol} / \mathrm{L}$,
$\mathrm{K} 4,5 \mathrm{mmol} / \mathrm{L}, \mathrm{Cl} 101 \mathrm{mmol} / \mathrm{L}$. She had no bleeding, and skin eruptions disappeared. Diagnosis was confirmed with blood sample tested in Refik Saydam National Public Health Agency Virology Reference and Research Laboratory by TaqMan based on one-step real-time PCR. Her IgM was positive and IgG was negative for CCHF.

\section{DISCUSSION}

Hyponatremia is life-threatening clinical condition. Although many clinical features are described in CCHF, hyponatremia has never been reported before. The CCHF cases in Turkey has increased dramatically in recent years (1). Because of endothelial damage in $\mathrm{CCHF}$, it can be seen with many different clinical manifestations, laboratory findings, and complications (5). CCHFV infection course has 4 distinct phases: incubation, prehemorrhagic, hemorrhagic, and convalescence period. The incubation period for CCHF differs from 2 to 9 days (6).

The majority (82\%) of patients have a history of tick bite. Fever (100\%), hemorrhagic symptoms (76\%), nausea-vomiting (60\%), tonsillopharyngitis (50\%), malaise (50\%), myalgia (46\%), and maculopapular rash (24\%) are the most common presenting clinical features (4). Hyponatremia or any electrolyte imbalance has not been reported before. In this case, our patient was admitted to hospital with fever and lethargy. Lethargy is not a common complaint in $\mathrm{CCHF}$, and also, electrolyte imbalance has not been reported before with CCHF (4).

Specific mechanisms underlie the pathogenesis of CCHF infection, and these mechanisms have not been clearly explained. Major targets of the CCHF virus are mononuclear phagocytes, hepatocytes, and endothelial cells (7). This shows that the virus may attack nearly all the systems in our body. Because of this, as a clinician, we can meet many different laboratory findings and clinical manifestations. Laboratory findings in CCHF show elevated liver enzymes, CK, LDH, increase in PT, aPTT, C-reactive protein (CRP) and D-dimer levels, decrease in fibrinogen levels, leukocytosis, leukopenia, and thrombocytopenia, and hepatomegaly and splenomegaly can be seen as clinical evidence.

Hyponatremia is the most common and serious disorder of electrolyte imbalance in hospitalized patients. Acute hyponatremia can cause substantial morbidity and mortality if not treated. The etiology of hyponatremia is various, and infections are common, which underlie this disorder. Our patient was euvolemic and had no edema. One of the criterion for diagnosing SIADH is decreased effective osmolality of the extracellular fluid (Posm < $275 \mathrm{mOsm} / \mathrm{kg} \mathrm{H} 2 \mathrm{O}$ ). Inappropriate urinary concentration (Uosm $>100 \mathrm{mOsm} / \mathrm{kg} \mathrm{H} 2 \mathrm{O}$ with normal renal function) at some level of plasma hypo-osmolality. Clinical euvolemia, as defined by the absence of signs of hypovolemia (orthostasis, tachycardia, decreased skin turgor, dry mucous membranes) or hypervolemia (subcutaneous edema, ascites). Elevated urinary sodium excretion (>30 mmol/L) while on normal salt and water intake (8). According to these criteria, our patient had SIADH.

\section{CONCLUSION}

In conclusion, this is the first case report of CCHF accompanied by SIADH in children. No CCHF-related hyponatremia has been reported in the literature. Because of this, clinicians must be careful of electrolyte imbalance in children who are diagnosed 
with CCHF. Electrolyte levels must be checked on admission and daily during hospitalization. This case report showed that SIADH can develop in children diagnosed with CCHF. Hyponatremia may be the cause of lethargy, and this can be regulated with sodium replacement treatment.

Informed Consent: Hastanın kimlik bilgileri ortaya koyan herhangi bir veri kullanılmamıştır. Hastadan onam alınması gereken herhangi bir girişim yapılmamıştır. Yerel etik kurula danışılmıştır ve bu vaka sunumu için onam alınmasına gerek görülmemiştir.

Peer-review: Externally peer-reviewed.

Author contributions: Concept - S.Ö., N.Ö.K., E.S.; Design S.Ö, N.Ö.K, E.K., R.Y.; Supervision - S.Ö., N.Ö.K., E.S., E.K, R.Y.; Funding - S.,Ö., N.Ö.K., E.S., E.K., R.Y.; Data Collection and/or Processing - S.Ö., N.Ö.K, E.K.; Analysis and/or Interpretation S.Ö., N.Ö.K., E.S., E.K., R.Y.; Literature Review - S.Ö., N.Ö.K., R.Y.; Writer - S.Ö, N.Ö.K., R.Y.; Critical Review - E.S., E.K., R.Y.

Conflict of Interest: No conflict of interest was declared by the authors.

Financial Disclosure: The authors declared that this study has received no financial support.

Hasta Onamı: Hastanın kimlik bilgileri ortaya koyan herhangi bir veri kullanılmamıştır. Hastadan onam alınması gereken herhangi bir girişim yapılmamıştır. Yerel etik kurula danışılmıştır ve bu vaka sunumu için onam alınmasına gerek görülmemiştir.

Hakem Değerlendirmesi: Dış Bağımsız

Yazar Katkıları: Fikir - S.Ö., N.Ö.K., E.S.; Tasarım - S.Ö., N.Ö.K, E.K., R.Y.,E.K.; Denetleme-S.Ö., N.Ö.K., E.S., E.K., R.Y.; Kaynaklar
- S.Ö., N.Ö.K., E.S., E.K., R.Y.; Veri Toplanması ve/veya işlemesi S.Ö., N.Ö.K, E.K.; Analiz ve/veya Yorum - S.Ö., N.Ö.K, E.S., E.K., R.Y.; Literatür taraması - S.Ö., N.Ö.K., R.Y.; Yazıyı Yazan - S.Ö., N.Ö.K., R.Y.; Eleştirel İnceleme - E.S., E.K., R.Y.

Çıkar Çatışması: Yazarlar çıkar çatışması bildirmemişlerdir.

Finansal Destek: Yazarlar bu çalışma için finansal destek almadıklarını beyan etmişlerdir.

\section{REFERENCES}

1. Tezer H, Sucakli IA, Sayli TR, Celikel E, Yakut I, Kara A, et al. Crimean-Congo hemorrhagic fever in children. J Clin Virol 2010; 48: 184-6. [CrossRef]

2. Aksoy HZ, Yilmaz G, Aksoy F, Koksal I. Crimean-Congo haemorrhagic fever presenting as epididymo-orchitis. J Clin Virol 2010; 48: 282-4. [CrossRef]

3. Bakir M, Ugurlu M, Dokuzoguz B, Bodur H, Tasyaran MA, Vahaboglu H. Crimean-Congo haemorrhagic fever outbreak in Middle Anatolia: a multicentre study of clinical features and outcome measures. J Med Microbiol 2005; 54: 385-9. [CrossRef]

4. Tuygun N, Tanir G, Caglayik DY, Uyar Y, Korukluoglu G, Cenesiz F. Pediatric cases of Crimean-Congo hemorrhagic fever in Turkey. Pediatr Int 2012; 54: 402-6. [CrossRef]

5. Guner R, Hasanoglu I, Yapar D, Tasyaran MA. A case of Crimean Congo hemorrhagic fever complicated with acalculous cholecystitis and intraabdominal abscess. J Clin Virol 2011; 50: 162-3. [CrossRef]

6. Tresallet C, Bastien L, Rabahi Y, Cadi M, Leroux G, Menegaux F. Hepatitis $C$ virus infection revealed by an acute acalculous cholecystitis. J Radiol 2010; 91: 813-5.

7. Oflaz MB, Kucukdurmaz Z, Guven AS, Karapinar H, Kaya A, Sancakdar $E$, et al. Bradycardia seen in children with crimean-congo hemorrhagic fever. Vector Borne Zoonotic Dis 2013; 13: 807-11. [CrossRef]

8. Verbalis JG, Goldsmith SR, Greenberg A, Korzelius C, Schrier RW, Sterns $\mathrm{RH}$, et al. Diagnosis, evaluation, and treatment of hyponatremia: expert panel recommendations. Am J Med 2013; 126: S1-42 [CrossRef] 